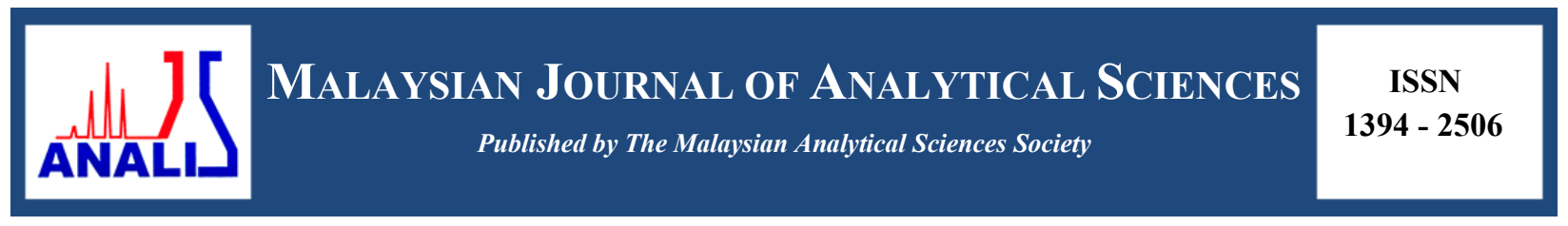

\title{
FILLER AND POLYMER INTERACTIONS IN POLYMETHYL METHACRYLATE/50\% EPOXIDIZED NATURAL RUBBER/SILICON DIOXIDE NANOCOMPOSITES
}

\author{
(Interaksi Pengisi Dan Polimer Dalam Nanokomposit Polimetil Metakrilat/Getah Asli \\ Terepoksida 50\%/Silikon Dioksida)
}

\author{
Sharil Fadli Mohamad Zamri ${ }^{1,2,3 *}$, Famiza Abdul Latif ${ }^{1,2,3}$, Ab Malik Marwan Ali $^{1,3}$, Ruhani Ibrahim", \\ Siti Izzati Husna Mohd Azuan ${ }^{1}$, Norashima Kamaluddin', Fitrah Hadip ${ }^{1}$ \\ ${ }^{1}$ Faculty of Applied Sciences \\ ${ }^{2}$ Synthesis and Application of Conducting Polymer Research Group \\ ${ }^{3}$ Frontier Materials \& Industry Application \\ Universiti Teknologi MARA, 40450 Shah Alam, Selangor, Malaysia \\ *Corresponding author: sharil7240@uitm.salam.edu.my
}

Received: 13 April 2017; Accepted: 4 June 2018

\begin{abstract}
Polymethyl methacrylate $/ 50 \%$ epoxidized natural rubber (PE) blend and polymethyl methacrylate $/ 50 \%$ epoxidized natural rubber/silicon dioxide (PE15) nanocomposites were successfully prepared via solvent casting method with tetrahydrofuran (THF) as solvent. The interactions between silicon dioxide $\left(\mathrm{SiO}_{2}\right)$ particles with polymethyl methacrylate (PMMA) and 50\% epoxidized natural rubber (ENR 50) in PE and PE15 films were investigated using Fourier transform infrared (FTIR) analysis. Meanwhile, the phase separation between PMMA and ENR 50 in PE and PE15 films was monitored using optical microscopy $(\mathrm{OM})$ analysis. FTIR analysis shows the presence of hydrogen bonding between PMMA and ENR 50 in PE film and functional groups responsible to the hydrogen bonding was identified. FTIR analysis also revealed that interactions between $\mathrm{SiO}_{2}$ with PMMA and ENR 50 were $\mathrm{SiO}_{2}$ weight percent dependent. While, OM analysis confirmed that phase separation between PMMA and ENR 50 also influenced by weight percent of $\mathrm{SiO}_{2}$.
\end{abstract}

Keywords: polymethyl methacrylate, $50 \%$ epoxidized natural rubber, silicon dioxide

\begin{abstract}
Abstrak
Adunan polimetil metakrilat/getah asli terepoksida 50\% (PE) dan nanokomposit polimetil metakrilat/getah asli terepoksida 50\%/silikon dioksida (PE15) telah berjaya disediakan melalui kaedah acuan tuangan larutan dengan tetrahidrofuran (THF) sebagai pelarut. Interaksi antara zarah silikon dioksida $\left(\mathrm{SiO}_{2}\right)$ dengan polimetil metakrilat (PMMA) dan getah asli terepoksida 50\% (ENR 50) dalam filem PE dan PE15 telah disiasat menggunakan analisis inframerah transformasi Fourier (FTIR). Sementara itu, fasa pemisahan antara PMMA dan ENR 50 dalam filem PE dan PE15 telah dipantau menggunakan analisis mikroskopi optik (OM). Analisis FTIR menunjukkan kewujudan ikatan hidrogen antara PMMA and ENR 50 dalam filem PE dan kumpulan berfungsi yang bertanggungjawab kepada ikatan hidrogen telah dikenalpasti. Analisis FTIR juga menunjukkan bahawa interaksi antara $\mathrm{SiO}_{2}$ dengan PMMA dan ENR 50 adalah bergantung kepada peratusan berat $\mathrm{SiO}_{2}$. Manakala, analisis OM mengesahkan bahawa fasa pemisahan antara PMMA dan ENR 50 juga dipengaruhi oleh peratusan berat $\mathrm{SiO}_{2}$.
\end{abstract}

Kata kunci: polimetil metakrilat, 50\% getah asli terepoksida, silikon dioksida 


\section{Introduction}

PMMA is a transparent polymer with superior physical properties include resistance to chemical, corrosion and weathering, light weight and good insulating properties [1]. However, PMMA may not be able to provide some of the targeted polymer's properties necessary for curtain applications [1,2]. This due to hard, brittle and rigid characteristics shown by PMMA [3]. Consequently, polymer blending is a simple, efficient and versatile modification approach that has been proposed to improve and tailor polymer properties [1]. It consists of two or more polymers mixed without involving new chemical bonding between its constituents [4]. In general, polymer blends show combination properties between both parent polymers that were mixed [5]. Previously, several polymer blends were investigated include polymethyl methacrylate-g-polyvinyl chloride/polymethyl methacrylate [2], polyethylene oxide/polymethyl methacrylate [3], polyethylene/polyamide [4], poly(2,6-dimethyl-1,4-phenylene ether)/poly(styrene-co-acrylonitrile) [5] and polypropylene/polyethylene [6]. Latif et al. reported that PMMA/ENR 50 blend with $10 \%$ ENR 50 composition lower the glass transition temperature $\left(T_{\mathrm{g}}\right)$ of PMMA and give a rubberlike characteristic to the PMMA/ENR 50 blend with excellent elasticity and adhesion properties [1]. Due to the rubbery properties of ENR 50.

Unfortunately, most polymer blends are not homogenized [1]. As result, polymer blends produced are inhomogeneous and cause phase separation $[7,8]$, thus performance of polymer blends may not be optimized [9, 10]. Interestingly, dispersion of inorganic filler in polymer blends were reported have the ability to improve the homogeneity and phase separation between polymers in the blending [11]. Besides, addition of inorganic fillers also has the ability to improve thermal stability [12] and mechanical stability [13] of the polymer nanocomposites. Among fillers were used in polymer blend include montmorillonite [4, 8], $\mathrm{SiO}_{2}[11,13]$ and titanium oxide $[12,13]$.

Solvent casting method is the most suitable method for preparation of polymer nanocomposites containing PMMA and ENR 50. This is due to the method can be carried out at room temperature, therefore, mixing polymers with different melting temperatures, thermal degradation of unstable polymer and evaporation of additives at high temperatures will be not concerned.

This study reports polymer nanocomposites were successfully prepared from PMMA, ENR 50 and $\mathrm{SiO}_{2}$ via solvent casting method. The presence of hydrogen bonding between PMMA and ENR 50 in the polymer blend was identified and functional groups responsible to the hydrogen bonding was suggested. In addition, the ability of $\mathrm{SiO}_{2}$ to occupy themselves in between PMMA and ENR 50 and manipulating the interaction between polymers and filler were discussed. The role of filler in improving miscibility and phase separation between PMMA and ENR 50 in PMMA/ENR 50 also was explained.

\section{Preparation of stock solutions}

\section{Materials and Methods}

$10.0 \mathrm{~g}$ of PMMA (Aldrich Chemistry, USA), $5.0 \mathrm{~g}$ of ENR 50 (Malaysia Rubber Board, Malaysia) and $10.0 \mathrm{~g}$ of 15 $\mathrm{nm} \mathrm{SiO}_{2}$ (Aldrich Chemistry, USA) were dissolved separately in $500 \mathrm{~mL}$ of THF (J.T. Baker) in $1 \mathrm{~L}$ screw cap bottles. The PMMA $(2 \%(\mathrm{w} / \mathrm{v}))$, ENR $50(1 \%(\mathrm{w} / \mathrm{v}))$, and $\mathrm{SiO}_{2}(2 \%(\mathrm{w} / \mathrm{v}))$ solutions were stirred for 24 hours using magnetic stirrers at room temperature. All solutions were kept in closed bottles and were stirred for an hour every time before use.

\section{Preparation of PMMA/ENR 50 blend and PMMA/ENR 50/SiO ${ }_{2}$ nanocomposites films}

$25.0 \mathrm{~mL}$ of PMMA and $5.0 \mathrm{~mL}$ of ENR 50 solutions were mixed and stirred to give PMMA:ENR 50 mass ratio of 90:10 in $100 \mathrm{~mL}$ screw cap bottles using magnetic stirrers for 24 hours. Then, $\mathrm{SiO}_{2}$ solution was added to the polymer mixtures at specific ratios (Table 1) and continuously stirred for another 24 hours. The polymer solutions were casted in Teflon dish under nitrogen gas flow for 12 hours. The obtained thin films then were peeled off, dried in an oven at a temperature of $50^{\circ} \mathrm{C}$ for 12 hours and kept in a desiccator. 
Table 1. $\mathrm{SiO}_{2}$ weight percent in the films

\begin{tabular}{ll}
\hline $\begin{array}{l}\text { Weight Percent of } \mathrm{SiO}_{2} \\
(\%)\end{array}$ & Designation \\
\hline 0 & PE \\
1 & PE151 \\
3 & PE153 \\
5 & PE155 \\
7 & PE157 \\
\hline
\end{tabular}

\section{Characterization: Fourier transform infrared spectroscopy analysis}

Perkin Elmer Spectrum One FTIR Spectrophotometer was used for FTIR analysis. The spectrum of all film samples were recorded at room temperature using the spectrophotometer that was equipped with Attenuated Total Reflectance (ATR) equipment. The scan wavenumber was fixed from 400 to $4000 \mathrm{~cm}^{-1}$ with resolution of $4 \mathrm{~cm}^{-1}$ and 16 times scan rate.

\section{Optical microscopy}

The surface of PE, PE151, PE153, PE155 and PE157 films was observed under Nikon ECLISPE ME 600 optical microscopy. Samples were placed onto the microscope slide and the brightness, the contrast, the lens distance and the magnification of the optical microscope were adjusted in order to obtain the best micrograph.

\section{Results and Discussion}

Latif et al. claimed that PMMA and ENR 50 polymer chains in PMMA/ENR 50 blend can interact via hydrogen bonding [1]. However, the exact functional groups involve in the hydrogen bonding is not further investigated. Since, $\mathrm{C}=\mathrm{O}$ and $\mathrm{O}-\mathrm{CH}_{3}$ groups of PMMA and $\mathrm{C}-\mathrm{O}-\mathrm{C}$ epoxy ring of ENR 50 are polar groups that have big potential to interact with any hydrogen atoms in ENR 50 and PMMA. Therefore, the effect of addition of $\mathrm{SiO}_{2}$ on PMMAENR 50, PMMA- $\mathrm{SiO}_{2}$ and ENR 50- $\mathrm{SiO}_{2}$ interactions were monitored using FTIR analysis. Figure 1 shows that PE film possesses $\mathrm{C}=\mathrm{O}, \mathrm{O}-\mathrm{CH}_{3}$ and $\mathrm{C}-\mathrm{O}-\mathrm{C}$ peaks that recorded at 1723,1380 and $1240 \mathrm{~cm}^{-1}$, respectively.

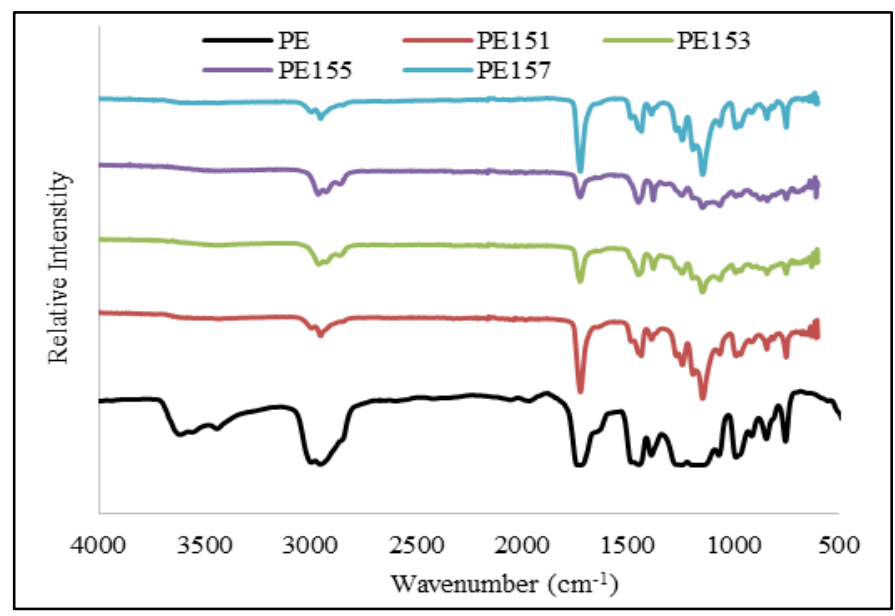

Figure 1. FTIR spectra corresponding to $\mathrm{PE}$ and $\mathrm{PE} 15$ films at various weight percent of $\mathrm{SiO}_{2}$ 
Interestingly, a broad peak in PE FTIR spectrum recorded at $3640 \mathrm{~cm}^{-1}$ was probably due to hydrogen bonding between ENR 50 and PMMA, and the possible molecular interactions are illustrated in Figure 2. The formation of hydrogen bonds was probably due to the polarity of $\mathrm{C}=\mathrm{O}, \mathrm{O}-\mathrm{CH}_{3}$ and $\mathrm{C}-\mathrm{O}-\mathrm{C}$ groups. Similar observation was reported in other blend systems containing ENR 50 [7] and PMMA [14].

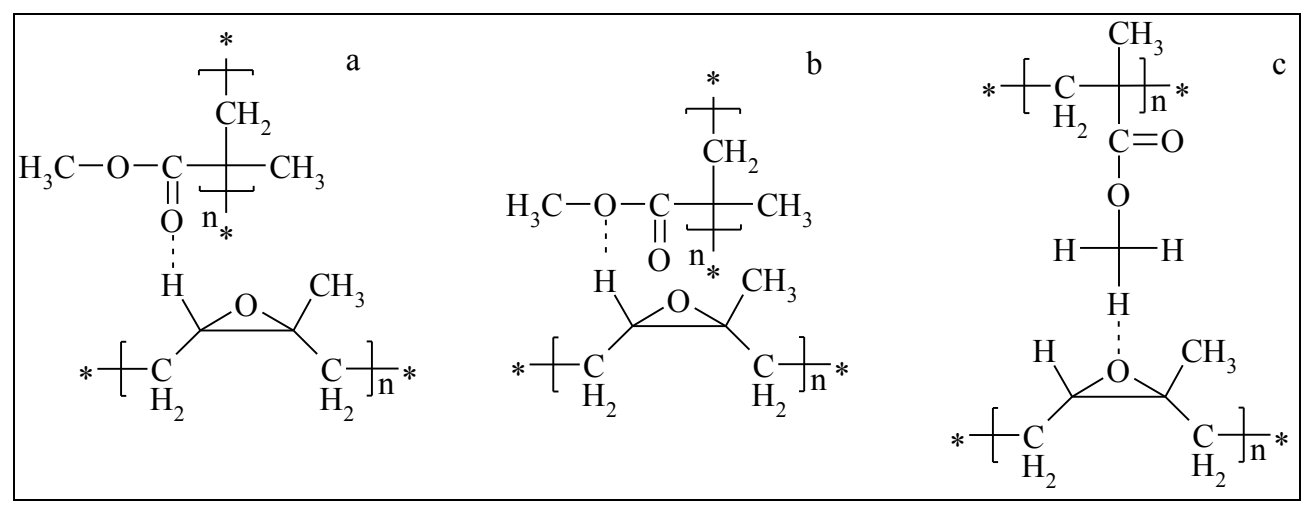

Figure 2. Possible hydrogen bonding between PMMA and ENR 50 in PMMA/ENR 50 blend

FTIR peaks comparison corresponding to $\mathrm{C}=\mathrm{O}, \mathrm{O}-\mathrm{CH}_{3}$ and $\mathrm{C}-\mathrm{O}-\mathrm{C}$ peaks of PMMA, ENR 50 and PE films was conducted to determine which among the functional groups in PMMA and ENR responsible for the hydrogen bond formed in PE film (Figure 3). It revealed that the intensity of $\mathrm{C}=\mathrm{O}$ peak of $\mathrm{PE}$ film was broader compared to PMMA film (Figure 3 (a)), whereas, C-O-C peak of PE film was decreased compared to ENR 50 film (Figure 3 (c)). Indicated that $\mathrm{C}=\mathrm{O}$ and $\mathrm{C}-\mathrm{O}-\mathrm{C}$ in $\mathrm{PE}$ film experienced strong interaction compared to PMMA and ENR 50

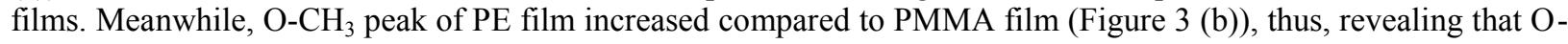
$\mathrm{CH}_{3}$ was free. From the observation it may suggest that oxygen atoms in $\mathrm{C}-\mathrm{O}-\mathrm{C}$ and $\mathrm{C}=\mathrm{O}$ group were responsible for the hydrogen bonding between PMMA and ENR 50 in PE film.
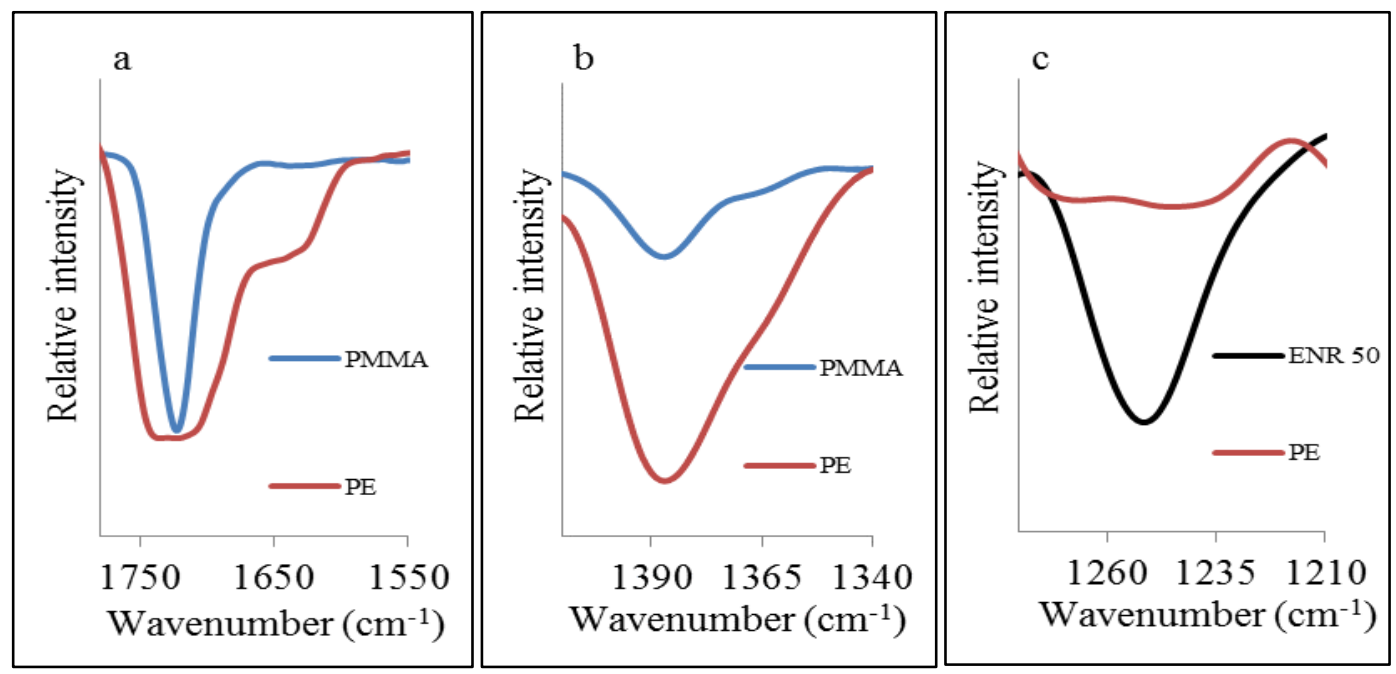

Figure 3. FTIR spectra corresponding a) $\mathrm{C}=\mathrm{O}$ b) $\mathrm{O}-\mathrm{CH}_{3}$ and c) $\mathrm{C}-\mathrm{O}-\mathrm{C}$ for PMMA, ENR 50 and PE films 
Interestingly, the O-H broad peak disappeared when $\mathrm{SiO}_{2}$ was dispersed in PE151, PE153, PE155 and PE157 films. This phenomenon is due to the ability of $\mathrm{SiO}_{2}$ particles to occupy itself in between polymeric chains and separate the polymer chains apart. As a result the number of hydrogen bonds reduced. This was further supported by an increase in intensity of $\mathrm{C}=\mathrm{O}$ (Figure 4 (a)) and $\mathrm{C}-\mathrm{O}-\mathrm{C}$ (Figure 4 (c)) peaks of $\mathrm{PE} 151$ film. $\mathrm{C}=\mathrm{O}$ and $\mathrm{C}-\mathrm{O}-\mathrm{C}$ groups in PE151 film were free since the number of hydrogen bonds between polymer chains in PE151 film was reduced when $\mathrm{SiO}_{2}$ was added.
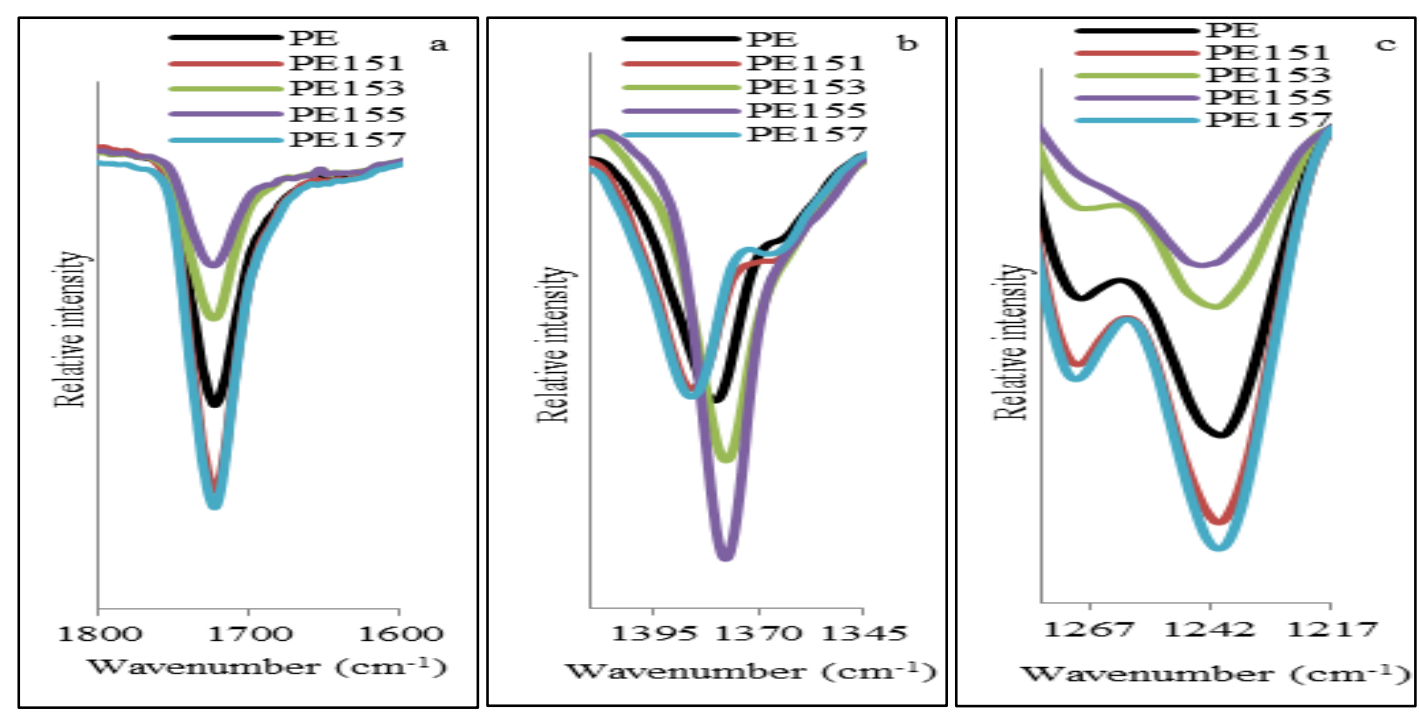

Figure 4. FTIR spectra corresponding to a) $\mathrm{C}=\mathrm{O}$ b) $\mathrm{O}-\mathrm{CH}_{3}$ and c) $\mathrm{C}-\mathrm{O}-\mathrm{C}$ groups in $\mathrm{PE}$ and $\mathrm{PE} 15$ films

It was observed that $\mathrm{O}-\mathrm{CH}_{3}$ peak in PE151 film (Figure 4 (b)) slightly decreased compared to PE film. This indicates that a new polymer network was formed between oxygen atoms in $\mathrm{O}_{-} \mathrm{CH}_{3}$ group and hydrogen atom in $\mathrm{Si}$ $\mathrm{OH}$ group of $\mathrm{SiO}_{2}$. The polymer network between PMMA and $\mathrm{SiO}_{2}$ interaction is illustrated in Figure 5 (c). Interestingly, the intensity of $\mathrm{C}=\mathrm{O}$ (Figure 4 (a)) and $\mathrm{C}-\mathrm{O}-\mathrm{C}$ (Figure 4 (c)) peaks in PE153 and PE155 films decreased when $3 \%$ and $5 \%$ of $\mathrm{SiO}_{2}$ was added. This was probably due to the polymer network moving between oxygen atoms of $\mathrm{C}=\mathrm{O}$ (Figure 5 (b)) and C-O-C (Figure 5 (c)) with hydrogen atom of Si-OH. Qu et al. also reported that $\mathrm{Si}-\mathrm{OH}$ group of $\mathrm{SiO}_{2}$ have the ability to interact with oxygen atom of polyamide [15]. In contrast, the intensity of $\mathrm{O}-\mathrm{CH}_{3}$ peak in PE153 and $\mathrm{PE} 155$ films increased when $3 \%$ and $5 \%$ of $\mathrm{SiO}_{2}$ was added indicating $\mathrm{O}-\mathrm{CH}_{3}$ group does not take place in the polymer network with Si-OH in PE153 and PE155 films.

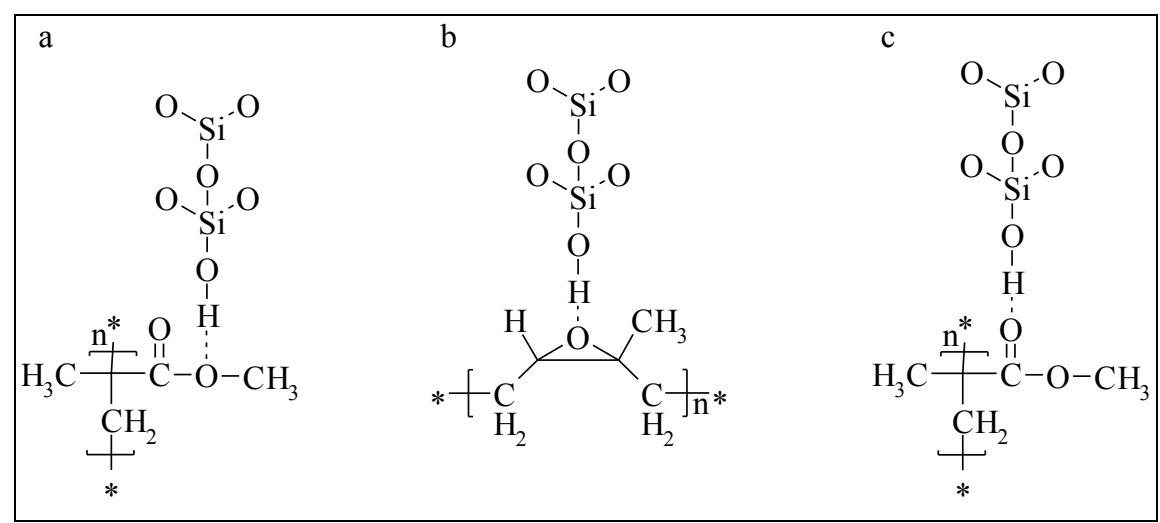

Figure 5. Possible polymer networks between $\mathrm{SiO}_{2}$ with PMMA and ENR 50 in PE15 films 
The phase separation between PMMA rich phase and ENR 50 rich phase were observed in PE film (Figure 6 (a). This observation confirmed that PMMA and ENR 50 in PE film was immiscible and was confirmed similar with our previous reports $[11,16]$. Therefore, the PMMA rich phase was observed as brown continuous phase meanwhile ENR 50 rich phase as fine hairy lines when the polymer blend examined under OM. Interestingly, reduction on the size of ENR 50 rich phase when $1 \%$ of $\mathrm{SiO}_{2}$ was added in PE151 (Figure 6 (b)) film indicated that the phase separation of PMMA and ENR 50 was improved. This probably due to the ability of $\mathrm{SiO}_{2}$ to occupy space between PMMA and ENR 50 hence forcing ENR 50 to move into PMMA phase [16]. The role of $\mathrm{SiO}_{2}$ as compatibilizer agent was also reported by Zhang et al. [17]. In their study, incompatible polypropylene/polystyrene (PP/PS) blend was successfully improved with addition of $\mathrm{SiO}_{2}$ in which of PS has been well distributed in the blend upon from addition of $\mathrm{SiO}_{2}$.

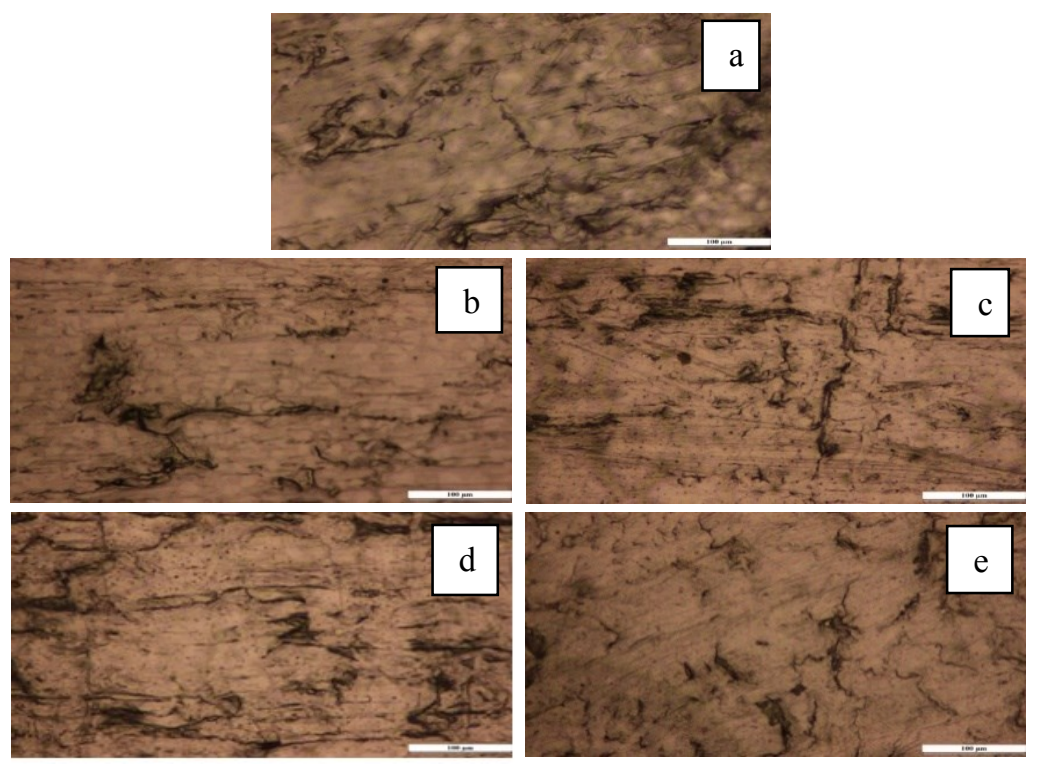

Figure 6. Optical micrographs for (a) PE, (b) PE151, (c) PE153, (d) PE155 and (e) PE157 films

Furthermore, the phase separation almost diminishing as the amount of $\mathrm{SiO}_{2}$ filler was increased up to $7 \%$ in the blend system (Figure 6 (e)). The improvement of the phase separation probably due to more $\mathrm{SiO}_{2}$ filler occupying space in the blend system. Similar observation was recorded by $\mathrm{Du}$ et al. when $5 \%$ of $\mathrm{SiO}_{2}$ was added in PMMA/SAN [18]. Uniquely, the harry lines of ENR 50 phase was found to be orientated in one direction at 1, 3 and $3 \%$ of $\mathrm{SiO}_{2}$ filler in PE151, PE153 and PE155 films, respectively. This was suggested that the interaction that occurred between the filler and the polymers as discussed previously.

In addition, as the amount of $\mathrm{SiO}_{2}$ increased up to $5 \%$, more $\mathrm{SiO}_{2}$ were distributed into the blend system hence initiate the formation of polymer network between oxygen atom of $\mathrm{C}-\mathrm{O}-\mathrm{C}$ (Figure 5 (b)) and $\mathrm{C}=\mathrm{O}$ (Figure 5 (c)) groups with hydrogen atom of the $\mathrm{Si}-\mathrm{OH}$. Since $\mathrm{C}=\mathrm{O}$ and $\mathrm{C}-\mathrm{O}-\mathrm{C}$ are more polar than the $\mathrm{O}_{-} \mathrm{CH}_{3}$, the filler seems to be attracted to these $\mathrm{C}=\mathrm{O}$ and $\mathrm{C}-\mathrm{O}-\mathrm{C}$ groups like a "magnetic effect" and form a series of $\mathrm{SiO}_{2}$ chain (Figure 7). This "magnetic effect" explained reason for the harry lines of ENR 50 phase and was observed to be orientated in one direction in its optical micrograph. 


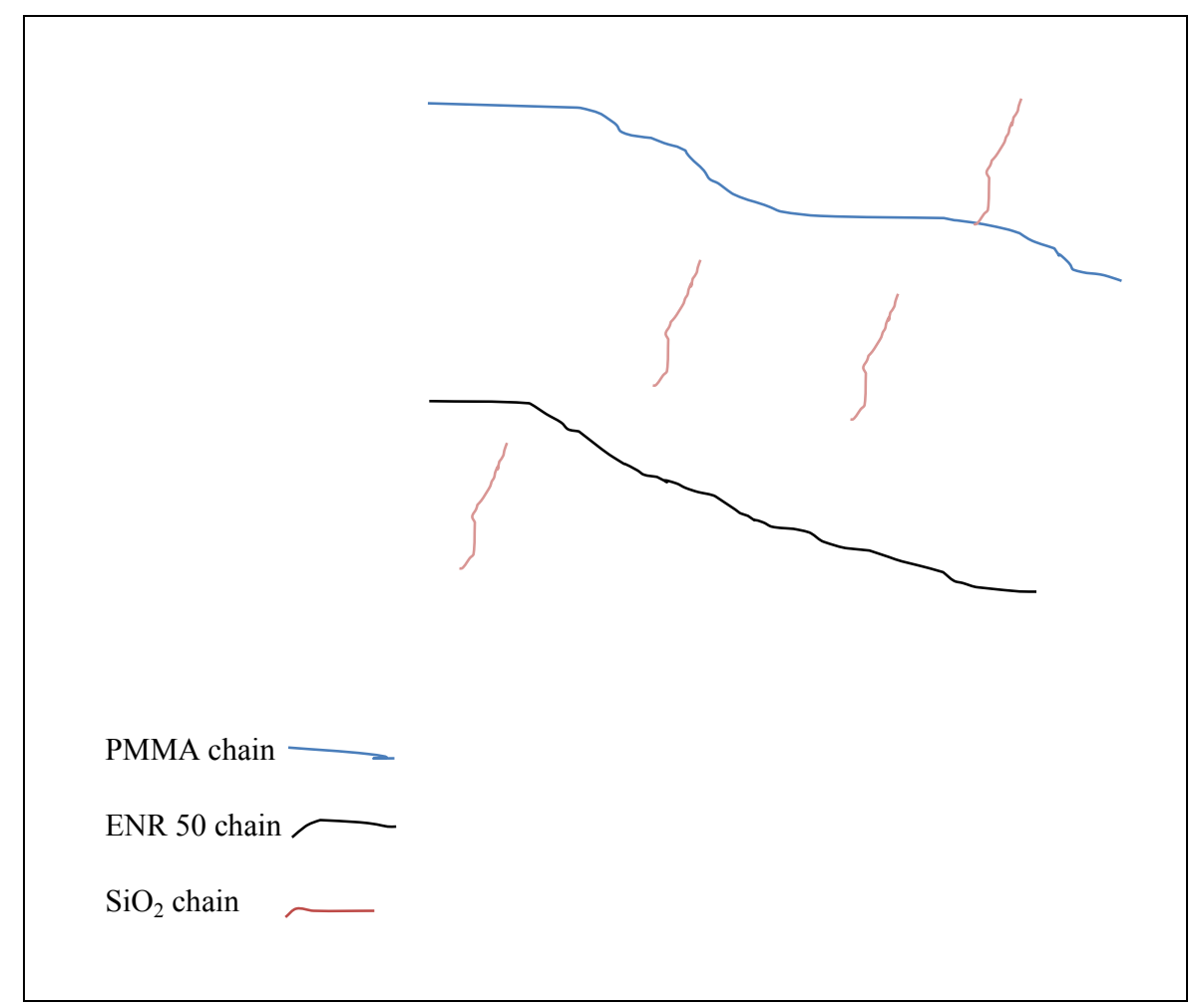

Figure 7. Propose magnetic effect of $\mathrm{SiO}_{2}$ on PMMA and ENR 50 chain in PMMA/ENR 50 blend

\section{Conclusion}

PMMA/ENR 50 blend and PMMA/ENR 50/ $\mathrm{SiO}_{2}$ nanocomposites films were successfully prepared via solvent casting method. Hydrogen bonding between PMMA and ENR 50 in the polymer blend was determined and functional groups responsible for the hydrogen bond was determined. The interactions between filler and polymers films were $\mathrm{SiO}_{2}$ weight percent dependent. PMMA and ENR 50 in PMMA/ENR 50 blend and PMMA/ENR 50/ $\mathrm{SiO}_{2}$ nanocomposites films were found immiscible. Interestingly, the miscibility between PMMA and ENR 50 improved when $\mathrm{SiO}_{2}$ was added. This finding is crucial for further investigation on the effects of $\mathrm{SiO}_{2}$ on physical, thermal and electrochemical properties of PMMA/ENR 50 electrolytes.

\section{Acknowledgement}

The authors would like to thanks Universiti Teknologi MARA for the technical support. Special thanks to the Ministry of Education (MOHE) of Malaysia for the financial support under Research Acculturation Grant Scheme (RAGS) (RAGS/2013/UiTM/SG06/1).

\section{References}

1. Latif, F. A., Aziz, M., Katun, K., Ali, M. A. M. and Yahya, M. Z. (2006). The role and impact of rubber in poly(methyl methacrylate)/lithium triflate electrolyte. Journal of Power Sources, 159: 1401-1404.

2. Yuan, W., Li, M. and Yang, M. (2006). Dual-phase polymer electrolyte with enhanced phase compatibility based on Poly(MMA-g-PVC)/PMMA. European Polymer Journal, 42: 1396-1402.

3. Sengwa, R. J., Dhatarwal, P. and Choudhary, S. (2014). Role of preparation methods on the structural and dielectric properties of plasticized polymer blend electrolytes: Correlation between ionic conductivity and dielectric parameters. Electrochimica Acta, 142: 359-370.

4. Huitric, J., Ville, J., Mederic, P. and Aubry, T. (2017). Solid-state morphology, structure, and tensile properties of polyethylene/polyamide/nanoclay blends: Effect of clay fraction. Polymer Testing, 58: 96-103. 
5. Bahrami, R., Lobling, T. I., Schmalz, H., Müller, A. H. E. and Altstadt, V. (2017). Synergistic effects of Janus particles and triblock terpolymers on toughness of immiscible polymer blends. Polymer, 109: 229-237.

6. Wong, A. C. Y. and Lam, F. (2002). Study of selected thermal characteristics of polypropylene/polyethylene binary blends using DSC and TGA. Polymer Testing, 21(6): 691-696.

7. Noriman, N. Z., Ismail, H. and Rashid, A. A. (2010). Characterization of styrene butadiene rubber/recycled acrylonitrile-butadiene rubber (SBR/NBRr) blends: The effects of epoxidized natural rubber (ENR-50) as a compatibilizer. Polymer Testing, 29(2): 200-208.

8. Arroyo, M., Manchado, M. A. L., Valentín, J. L. and Carretero, J. (2007). Morphology/behaviour relationship of nanocomposites based on natural rubber/epoxidized natural rubber blends. Composites Science and Technology, 67: 1330-1339.

9. Ploypetchara, N., Suppakul, P., Atong, D. and Pechyen, C. (2014). Blend of polypropylene/poly(lactic acid) for medical packaging application: physicochemical, thermal, mechanical, and barrier properties. Energy Procedia, 56: 201-210.

10. Takayama, T., Todo, M. and Tsuji, H. (2011). Effect of annealing on the mechanical properties of PLA/PCL and PLA/PCL/LTI polymer blends. Journal of the Mechanical Behavior of Biomedical Materials, 4 (3): 255 260.

11. Zamri, S. F. M. and Latif, F. A. (2013). $\mathrm{SiO}_{2}$ filler as interface modifier in PMMA/ENR 50 electrolytes. Advanced Materials Research, 812: 120-124.

12. Pradeepa, P., Raj, S. E and Prabhu, M. R. (2015). Effects of ceramic filler in poly(vinyl chloride)/poly(ethyl methacrylate) based polymer blend electrolytes. Chinese Chemical Letters, 26: 1191-1196.

13. Hema, M. and Tamilselvi, P. (2016). Lithium ion conducting PVA:PVdF polymer electrolytes doped with nano $\mathrm{SiO}_{2}$ and $\mathrm{TiO}_{2}$ filler. Journal of Physics and Chemistry of Solids, 96 - 97: 42-48.

14. Huang, C. F. and Chang, F. C. (2003). Comparison of hydrogen bonding interaction between PMMA/PMAA blends and PMMA-co-PMAA copolymers. Polymer, 44(10): 2965-2974.

15. Qu, C., Yang, H., Liang, D., Cao, W. and Fu, Q. (2007). Morphology and Properties of PET/PA-6/SiO $\mathrm{S}_{2}$ Ternary Composites. Journal of Applied Polymer Science, 104: 2288-2296.

16. Zamri, S. F. M., Latif, F. A., Ali, A. M. M., Ibrahim, R., Azuan, H. I. H. M, Kamaluddin, N. and Hadip, F. (2017). Exploration on effects of $15 \mathrm{~nm} \mathrm{SiO}{ }_{2}$ filler on miscibility, thermal stability and ionic conductivity of PMMA/ENR 50 electrolytes. AIP Conference Proceedings, 1809: 020049.

17. Zhang, Q., Yang, H. and Fu, Q. (2004). Kinetics-controlled compatibilization of immiscible polypropylene /polystyrene blends using nano- $\mathrm{SiO}_{2}$ particles. Polymer, 45(6): 1913-1922.

18. Du, M., Wu, Q., Zuo, M. and Zheng, Q. (2013) Filler effects on the phase separation behavior of poly (methyl methacrylate)/poly (styrene-co-acrylonitrile) binary polymer blends. European Polymer Journal, 49(9): 27212729. 